\title{
Optimum Physico-Chemical and Processing Parameters for the Preservation of King Coconut Water
}

\author{
K.D.P.P. Gunathilake ${ }^{1 *}$, R.M.C.N. Rathnayake ${ }^{2}$
}

\begin{abstract}
King coconut (Cocos nucifera var. aurantiaca) water is a natural, nutritious and healthy beverage. However, it is underutilized in terms of value addition with extended shelf life. Therefore, an attempt was made to develop the physico-chemical and processing parameters for the value addition of King coconut water with extended shelf life. King coconut water was analyzed for sugar, minerals and vitamin $\mathrm{C}$ content based on reviewed methods. Studies were conducted to identify the optimum $\mathrm{pH}$, total soluble solid (TSS), type of acidulant and pasteurization conditions based on sensory properties of the product using semi trained panelists. Processed King coconut water was packed in three different packages and stored at refrigerated $\left(4^{\circ} \mathrm{C}\right)$ condition for two months. Changes in $\mathrm{pH}$, TSS and titratable acidity were evaluated in two weeks intervals throughout the storage period. The results showed that optimum $\mathrm{pH}$, TSS, type of acidulant and pasteurization conditions were $4.4,9$, malic acid and $70^{\circ} \mathrm{C} / 15$ sec., respectively. The product was microbiologically (less than $50 \mathrm{CFU} / \mathrm{ml}$ ) safe for consumption even after 8 weeks of storage. These storage studies revealed that the changes in $\mathrm{pH}$, TSS and titratble acidity of King coconut water packed in three packaging materials had no significant difference $(\mathrm{p}<0.05)$ during refrigerated storage.
\end{abstract}

Keywords: King coconut, pasteurization, physico-chemical

${ }^{1}$ Coconut Processing Research Division, Coconut Research Institute, Lunuwila 61150, Sri Lanka.

*Email: kdppgunathilake@yahoo.com

(*current address: 106/3, Palenwatta, Pannipitiya, Sri Lanka)

${ }^{2}$ Department of Food Science \& Technology, Faculty of Agriculture, University of Peradeniya, Sri Lanka. 


\section{Introduction}

King coconut, in Sri Lanka called as 'thembili' which belongs to the semi-tall variety aurantiaca within the species Cocos nucifera, which is endemic to Sri Lanka. King coconut cultivation in Sri Lanka has been estimated in 1.19 million palms throughout the country except the northern part (Department of Census and Statistics, 2004). The King coconut water is a nutritious natural beverage which is rich in sugar, specially reducing sugar, and minerals mainly potassium (Jayasekera, 1990; Ediriweera, 1996). King coconut water has a high market potential in foreign countries. Although King coconut water is very popular natural beverage, processed King coconut water is not much available and still rare. Therefore, development of processing technologies to extend the shelf life of King coconut water is vital for the sustainability of the King coconut cultivation and make them available to the world. An attempt was made to develop processing technologies for the extension of shelf life of King coconut water. The main objectives of this study are to determine the quality of King coconut water and identify the physico-chemical and processing parameters required for the preservation of King coconut water at refrigerated conditions.

\section{Materials and Methods}

King coconuts were harvested from a plantation in Bandirippuwa estate of Coconut Research Institute of Sri Lanka. Food grade chemicals such as sucrose and organic acids (citric acid, malic acid and ascorbic acid) were purchased from a local supplier in Sri Lanka. All the chemicals used for the analysis were analytical grade.

\section{Optimization of processing parameters}

Sensory based physic-chemical optimization trials were carried out to identify the best acidulant (among malic acid, citric acid and ascorbic acid and combinations of them) and the optimum levels of TSS (Brix 5-9), $\mathrm{pH}$ (4.04.7) of King coconut water for the development of shelf stable ready to serve packaged product were also determined. Different time- temperature combinations were tested to determine the optimum pasteurization conditions. Eighteen semi trained panelists and 5 point hedonic scale were used for these process optimization studies.

\section{Treatments}

King coconuts were opened and coconut water was collected to a stainless steel container and TSS (Brix) and $\mathrm{pH}$ were adjusted using sugar and malic acid respectively. Brix and $\mathrm{pH}$ adjusted King coconut water was pasteurized at $72^{\circ} \mathrm{C}$ for 15 seconds and filled into three packing materials separately while hot. Packaging materials used were glass bottles, triple laminated aluminum packets and linear low density polythene (LLDPE)/nylon laminates. King coconut water in equal 15 packages was stored at refrigerated storage conditions (temperatures $4.0 \pm 0.2^{\circ} \mathrm{C}$ ). The relative humidity of the storage was ranged between $63-74 \%$.

\section{Sensory Evaluation}

Using 5-point hedonic scales $(5=$ excellent, $1=$ very bad), eighteen semi trained judges were asked to evaluate the overall acceptability of the King coconut water. At each session, judges were served with a white plastic cup containing about $200 \mathrm{ml}$ of coconut water.

\section{Physicochemical Analysis}

The composition of the King coconut water was analyzed in triplicate for all parameters. Total solids and ash content were determined by using the method described in Ranganna (2000). Total sugars were determined by using a colorimetric method described by Dubois et al., 1956. Absorbance was measured at $645 \mathrm{~nm}$ using UV/VIS spectrophotometer (Shimadzu UV 160-A, Japan). Sodium and Potassium content were measured at $589 \mathrm{~nm}$ for $\mathrm{Na}^{+}$and $766.5 \mathrm{~nm}$ for $\mathrm{K}^{+}$using Atomic Absorption Spectrophotometer (GBC 904 AA, Japan) according the method described in Association of Analytical Chemists (AOAC, 1995). Calcium and magnesium content was measured at $422.7 \mathrm{~nm}$ (for $\mathrm{Ca}^{2+}$ ) and $285.2 \mathrm{~nm}$ (for $\mathrm{Mg}^{2+}$ ) using the AOAC, (1995). Total soluble solid or Brix of coconut water was measured using a hand held refractometer 
(ATAGO NI-E). Total acidity was measured by titrating with $0.1 \mathrm{~N} \mathrm{NaOH}$ and phenolphthalein as indicator and calculated as percentage of citric acid (Ranganna, 2000). The $\mathrm{pH}$ was determined using TOA IM-450 pH meter at $25^{\circ} \mathrm{C}$. Ascorbic acid content of King coconut water was determined by using Ranganna, 2000.

\section{Shelf life study}

Shelf life of the processed King coconut water was studied at refrigerated storage conditions. Products were evaluated for the changes in $\mathrm{pH}$, TSS and acidity at 2 weeks intervals up to 2 months periods.

\section{Microbial quality}

Microbial analyses were done by serial dilution of the pour plate method described in AOAC (1995). Microbial counts were used to determine the optimum heat treatment to achieve commercial sterility.

\section{Statistical analysis}

The data were analyzed and obtained mean and standard deviation. Mean comparison was done using ANOVA and Independent sample ttest using SPSS 10 statistical package. Data obtained from sensory evaluation were analyzed by MINITAB Statistical package using Friedman test.

\section{Results and Discussion}

\section{Chemical composition}

The edible part of the coconut fruit, coconut meat and coconut water, is the endosperm tissue. The composition of coconut water is shown in Table 1. However, fresh King coconut water is a relatively dilute system with total solids content of $5 \%$ and total sugars of $3.46 \%$. The main sugar fractions of young coconuts are glucose and fructose, while sucrose predominates in mature meat (Pandolina, 1983). It is a nutritive beverage, furnishing fluid plus potassium, magnesium, calcium and sodium. According to the Table 1, coconut water contains about $2140 \mathrm{ppm}$ potassium along with other minerals indicating that King coconut water is a good source of minerals. Reviewed literature also supports that the coconut water contains a variety of inorganic ions (Jean et al., 1961; USDA, 2008) and these ions contribute to the therapeutic value inherent in coconut water. As the basic ion composition of coconut water can replenish the electrolytes of the human body excreted through sweat and urine, such as sodium, potassium, magnesium and calcium, it can serve as an effective rehydration drink (Saat et al., 2002). Interestingly, Anurag and Rajamohan, 2003 showed that coconut water has cardio-protective effects in experimental myocardial infarction induced in rats and this was probably attributed to the rich content of mineral ions in coconut water, especially potassium.

In addition to minerals, coconut water contains vitamin $\mathrm{C}$ (total ascorbic acid, Table 1), which is an important dietary antioxidant (Shenkin, 2006; Rattan, 1994). Vitamin C content of processed King coconut water is low significantly compared with fresh King coconut water indicating loss of vitamin $\mathrm{C}$ during pasteurization acid since ascorbic acid or vitamin $\mathrm{C}$ is heat labile. Coconut water contains vitamins B1, B2, B3, B5, B6, B7 and B9. The B vitamins are water-soluble and are required as coenzymes for enzymatic reactions essential for cellular function (Jean et al., 2009). Furthermore, micronutrients such as inorganic ions and vitamins in coconut water play a vital role in human body antioxidant system (Evans and Halliwell, 2001). The chemical composition of coconut water in general is affected by several factors. Jackson et al., 2004 showed that coconut water of different coconut varieties contains different concentration of compounds, and that the chemical contents also varied during the different stages of maturity, soil and environmental conditions. Titratable acidity and $\mathrm{pH}$ of the fresh King coconut was $0.15 \%$ and 5.34 respectively.

\section{Optimization of physical chemical and processing parameters}

Preliminary studies were conducted to identify the optimum physico-chemical and processing conditions based on sensory evaluation by using a semi trained panelists. Four levels of $\mathrm{pH}$ were evaluated within the 
Table 1. Chemical composition of King coconut water

\begin{tabular}{|l|c|c|}
\hline \multicolumn{1}{|c|}{ Component } & Fresh King coconut water & Processed King coconut water \\
\hline $\mathrm{pH}$ & 5.34 & 4.4 \\
Titratable acidity (\%) & 0.15 & 0.70 \\
TSS $\left({ }^{0} \mathrm{Brix}\right)$ & 5.0 & 9.0 \\
Total sugar $(\mathrm{g} / 100 \mathrm{ml})$ & 3.46 & 7.42 \\
Ascorbic acid $(\mathrm{ppm})$ & $436 \pm 12.4$ & $88 \pm 5.32$ \\
Minerals: $\mathrm{Na}^{+}(\mathrm{ppm})$ & $87 \pm 4.86$ & $87 \pm 3.90$ \\
$\mathrm{~K}^{+}(\mathrm{ppm})$ & $2141+26.2$ & $2142 \pm 67.32$ \\
$\mathrm{Ca}^{2+}(\mathrm{ppm})$ & $100.4 .2 \pm$ & $100 \pm 5.98$ \\
$\mathrm{Mg}^{2+}(\mathrm{ppm})$ & $42 \pm 3.1$ & $42 \pm 1.45$ \\
\hline
\end{tabular}

Table 2. Changes in pH, TSS and TA of King coconut water in different packages during 8 weeks of storage

\begin{tabular}{|l|l|l|l|l|l|l|}
\hline & Packages & $\mathbf{0}$ week & $\mathbf{2}^{\text {nd }}$ week & $\mathbf{4}^{\text {th }}$ week & $\mathbf{6}^{\text {th }}$ week & $\mathbf{8}^{\text {th }}$ week \\
\hline $\mathrm{pH}$ & Bottles & $4.40 \pm 0.2 \mathrm{a}$ & $4.40 \pm 0.1 \mathrm{a}$ & $4.40 \pm 0.2 \mathrm{a}$ & $4.50 \pm 0.2 \mathrm{a}$ & $4.50 \pm 0.1 \mathrm{a}$ \\
& LDPE/Ny & $4.40 \pm 0.3 \mathrm{a}$ & $4.40 \pm 0.0 \mathrm{a}$ & $4.45 \pm 0.5 \mathrm{a}$ & $4.50 \pm 0.2 \mathrm{a}$ & $4.45 \pm 0.2 \mathrm{a}$ \\
& TLA & $4.40 \pm 0.5 \mathrm{a}$ & $4.40 \pm 0.2 \mathrm{a}$ & $4.45 \pm 0.5 \mathrm{a}$ & $4.45 \pm 0.2 \mathrm{a}$ & $4.50 \pm 0.4 \mathrm{a}$ \\
\hline TSS $\left({ }^{0} \mathrm{Bx}\right)$ & Bottles & $9.0 \pm 0.0 \mathrm{a}$ & $9.0 \pm 0.3 \mathrm{a}$ & $9.0 \pm 0.3 \mathrm{a}$ & $9.0 \pm 0.2 \mathrm{a}$ & $8.0 \pm 0.5 \mathrm{a}$ \\
& LDPE/Ny & $9.0 \pm 0.3 \mathrm{a}$ & $9.0 \pm 0.0 \mathrm{a}$ & $9.0 \pm 0.0 \mathrm{a}$ & $8.5 \pm 0.5 \mathrm{a}$ & $8.5 \pm 0.5 \mathrm{a}$ \\
& TLA & $9.0 \pm 0.3 \mathrm{a}$ & $9.0 \pm 0.3 \mathrm{a}$ & $9.0 \pm 0.3 \mathrm{a}$ & $9.0 \pm 0.2 \mathrm{a}$ & $9.0 \pm 0.3 \mathrm{a}$ \\
\hline TA $(\%)$ & Bottles & $0.15 \pm 0.05 \mathrm{a}$ & $0.15 \pm 0.4 \mathrm{a}$ & $0.15 \pm 0.05 \mathrm{a}$ & $0.20 \pm 0.02 \mathrm{a}$ & $0.20 \pm 0.02 \mathrm{a}$ \\
& LDPE/Ny & $0.15 \pm 0.03 \mathrm{a}$ & $0.15 \pm 0.6 \mathrm{a}$ & $0.20 \pm 0.04 \mathrm{a}$ & $0.15 \pm 0.08 \mathrm{a}$ & $0.20 \pm 0.06 \mathrm{a}$ \\
& TLA & $0.15 \pm 0.05 \mathrm{a}$ & $0.15 \pm 0.4 \mathrm{a}$ & $0.15 \pm 0.15 \mathrm{a}$ & $0.20 \pm 0.02 \mathrm{a}$ & $0.20 \pm 0.02 \mathrm{a}$ \\
\hline
\end{tabular}

Values with same letters are not significantly different $(p<0.05)$

range of 4.0-4.7 and it was found that mean sensory scores for the King coconut water within the selected $\mathrm{pH}$ range insignificant $(\mathrm{p}<0.05)$ (Figure 1). The limiting $\mathrm{pH}$ for most food poisoning bacteria is 4.5 (Jay, 1996). Therefore $\mathrm{pH}$ level 4.4 was selected for the processing of King coconut water to extend the shelf life. Figure 2 shows the mean sensory scores for King coconut water with different brix values. There was a significant difference observed among different brix values. King coconut water with the $9^{0} \mathrm{Bx}$ was received the highest means sensory scores and therefore that brix level was selected for optimum brix or TSS. Malic acid, citric acid, ascorbic acid and combinations of these organic acids were studied to identify the best acidulant to be used for the acidification or bring down the $\mathrm{pH}$ of King coconut water to the optimum level. Based on the sensory evaluation of King coconut water acidified with different acidulant, it was found that there were no significant difference among the acidulant tested (Figure 3). Estimated median value for taste was highest for malic acid, so it was used as acidulant for young King coconut water processing. Four different timetemperature combinations were evaluated to identify the optimum processing conditions. Based on the sensory evaluation of pasteurized King coconut water, sample with highest sensory mean scores was selected for the optimum processing conditions. According to the statistical analysis, King coconut water processed at $72^{\circ} \mathrm{C}$ for 15 seconds scored the highest mean sensory scores compare with other processing conditions (Figure 4). This may be due to the use of lowest processing time used compared with other processing conditions. 
Figure 1. Sensory scores for King coconut water with different $\mathbf{p H}$ levels Columns with same letters are not significantly different $(\mathrm{p}<0.05)$

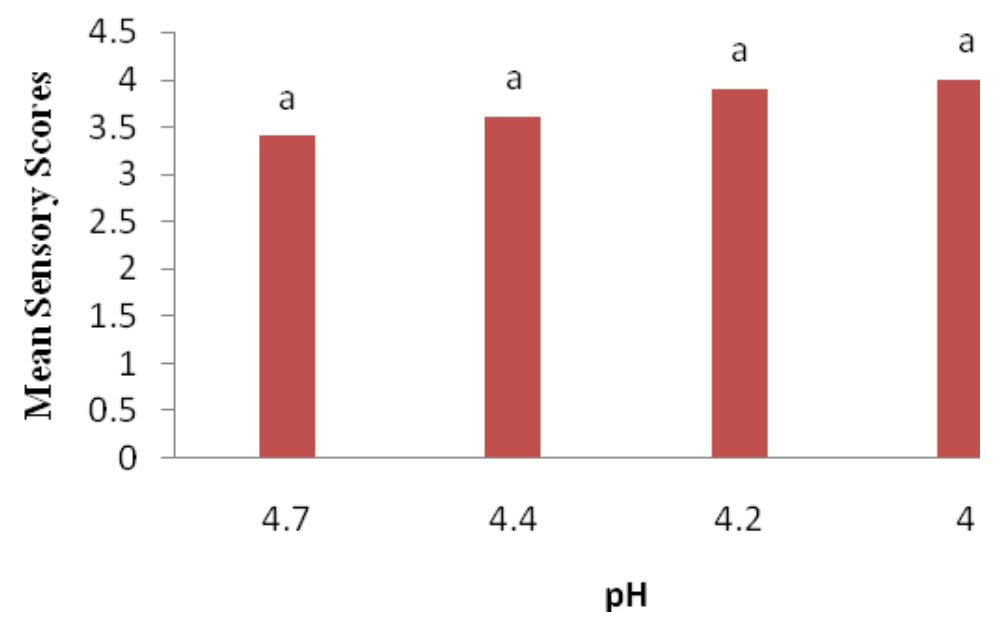

Figure 2. Sensory scores for King coconut water with different TSS levels Columns with same letters are not significantly different $(\mathrm{p}<0.05)$

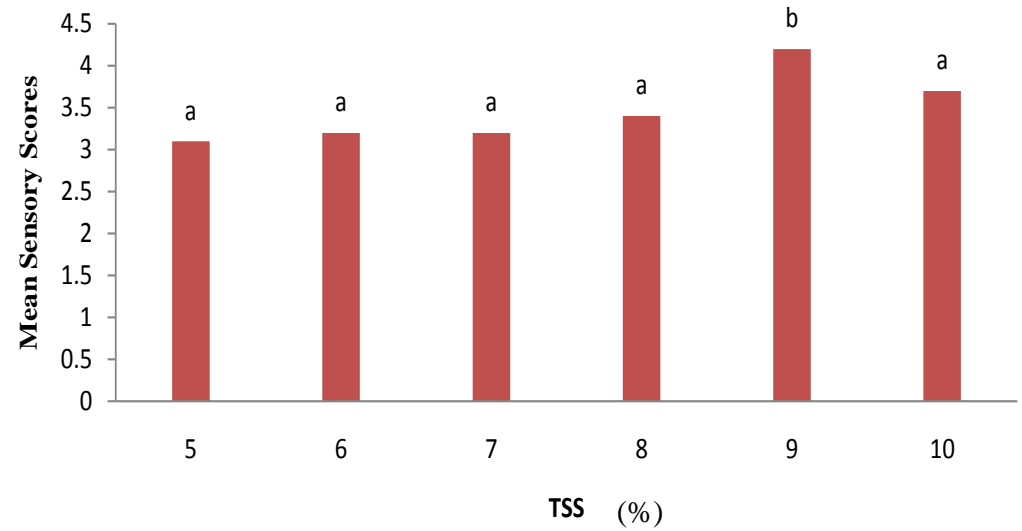


Figure 3. Sensory scores for King coconut water with different acidulant types (at pH of 4.40 and TSS of 9.0)

Columns with same letters are not significantly different $(\mathrm{p}<0.05)$

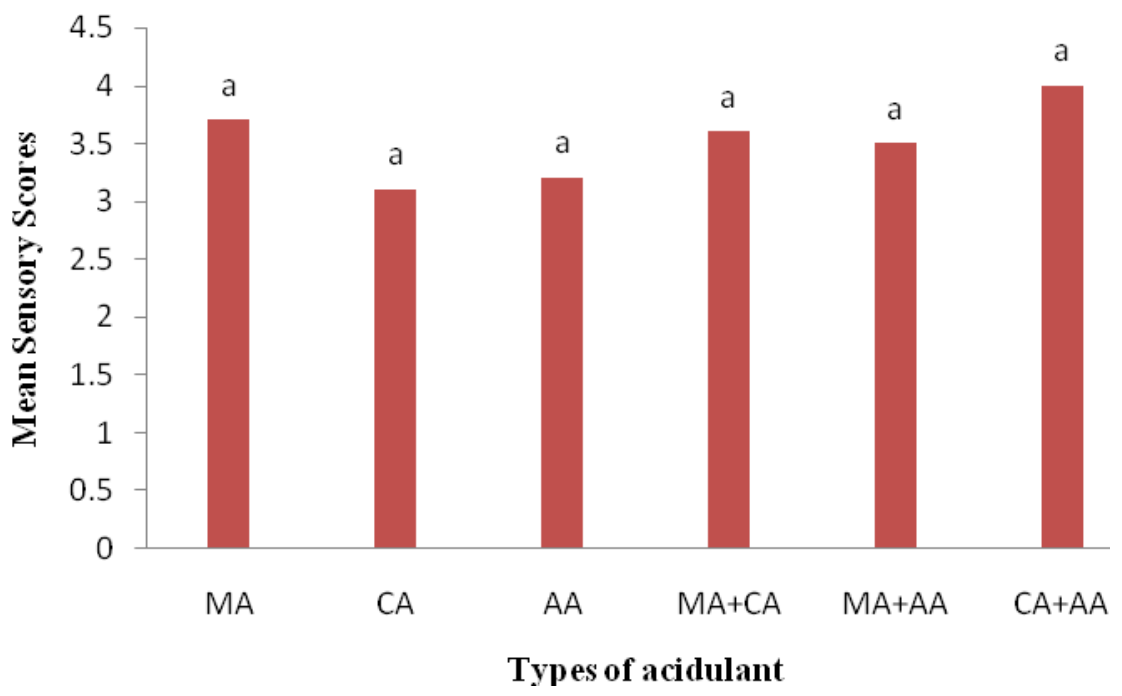

Figure 4. Sensory scores for King coconut water with different pasteurization conditions Columns with same letters are not significantly different $(\mathrm{p}<0.05)$

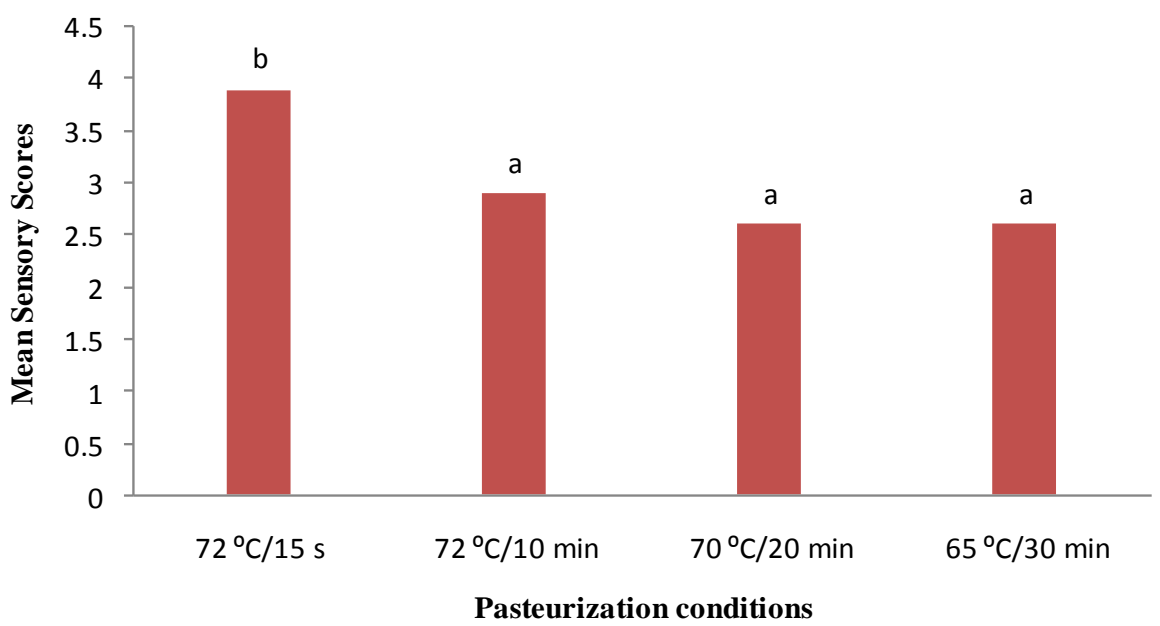




\section{Shelf life study}

Pasteurized King coconut water was stored at refrigerated conditions for two months. During the storage period $\mathrm{pH}$, TSS and titratable acidity were monitored. These storage studies revealed that the changes in $\mathrm{pH}$, TSS and titratable acidity of King coconut water packed in different packaging materials was insignificant $(p<0.05)$ during refrigerated storage (Table 2). Total plate counts of King coconut water packed in different packing materials were analyzed using the method described in Ranganna, 2000. The total plate count was within the acceptable level (less than 50 in $1 \mathrm{ml}$ ) at each packaging and confirmed Sri Lankan Standard Institute (SLS 729, 1985) indicating that the product was microbiologically safe for consumption. However, it was noticed that there was deposition of white colour sediments after two weeks storage. This may be due to deposition of denatured protein during storage and further research is needed to identify the methods to overcome this. Furthermore, a pink colour development was found in King coconut water after 6 weeks of storage. According to the Jansz et al., 1992, young coconut water when maintained under sterile conditions develops a pink colouration. They indicated that this is due to a 5,6 indole, quinine produced by oxidation of tyrosine.

\section{Conclusion}

The optimum pasteurized condition is 72 ${ }^{0} \mathrm{C}$ for 15 seconds, since processed King coconut and storage gave rise to highest TSS $\left(9^{\circ} \mathrm{Bx}\right)$ and highest mean sensory scores, and its $\mathrm{pH}$ and Titratable acidity are 4.4 and $0.7 \%$ respectively.

This condition can prolong the shelf life of King coconut in the refrigerator for 8 weeks. And the product would be microbiologically safe for consumption.

The three packaging methods of processed King coconut water had no significant difference on their physico-chemical parameters.

\section{Acknowledgement}

The authors are deeply grateful the Dr. C. Jayasekera, former director of Coconut Research Institute and the staff of Coconut Processing Research Division of the institute for various supports.

\section{References}

Alleyne, T., Roache, S.; Thomas, C.; Shirley, A. (2005).The control of hypertension by use of coconut water and mauby: Two tropical food drinks. West Indian Medical. Journal, 54, 3-8.

Anurag, P., Rajamohan, T. (2003). Cardioprotective effect of tender coconut water in experimental myocardial infarction. Plant Foods \& Human Nutrition, 58, 1-12

Department of Census and Statistics. (2004), Sri Lanka.

DuBois, M.; Gilles, K.A.; Hamilton, J.K.; Rebers, P.A.; Smith, F. (1956). Colorimetric Method for Determination of Sugars and Related Substances. Analytical Chemistry, 28 (3), 350-356

Ediriweera, N.D. (1996). King coconut. CORD XII, 2, 43-47

Evans, P.; Halliwell, B. (2001). Micronutrients: Oxidant/antioxidant Status. British Journal Nutrition, 85, 67-74

Jackson, J.C.; Gordon, A.; Wizzard, G.; McCook, K.; Rolle, R. (2004). Changes in chemical composition of coconut (Cocos nucifera L.) water during maturation of the fruit. Journal of Science in Food \& Agriculture. 4, 84, 1049-1052.

Jansz, E.R., Rabel, C.S., Marikar, F.A. (1992). Some factors affecting the development of pink colour in coconut water. Journal National Science Council, Sri Lanka, 20(1), 107-113 
Jay, J.M.I. (1996). Modern food microbiology, $5^{\text {th }}$ edition, Chapman and Hall, New York.

Jayasekara, C. (1990). High Performance Liquid Chromatographic analysis of carbohydrates in King coconut and ordinary coconut water. Paper presented at the "Workshop on carbohydrates and carbohydrate containing natural products". University of Peradeniya, Peradeniya. 1216

Jean W. H.; Yong, L. G., Yan F. N. and Swee N. T. (2009) The Chemical Composition and Biological Properties of Coconut (Cocos nucifera L.) Water, A review. Molecules, 14

Pandolina, W.C. (1983). Coconut water and coconut sap. Suggestions for Research and Development. Presented at the "Miniworkshop on water and sap utilization" sponsored by PCARRO e PCREDF, Metro Manila, Sept. 20.

Ranganna, S. (2000). In handbook of analysis and quality control for fruits and vegetable products. pp 5-36. Tata Mc Graw - Hill publishing company Ltd, New Delhi.

Rattan, S.I.S. and B.F.C. Clark, (1994). Kinetin delays the onset of ageing characteristics in human fibroblasts. Biochem. Biophys. Res., 201: 665-672

Saat, M.; Singh, R.; Sirisinghe, R.G.; Nawawi, M. (2002). Rehydration after exercise with fresh young coconut water, carbohydrateelectrolyte beverage and plain water. Journal of Physiololgy Anthropololgy \& Applied.Human Science, 21, 93-104

Santoso, U.; Kubo, K.; Ota, T.; Tadokoro, T.; Maekawa, A. (1996). Nutrient composition of kopyor coconuts (Cocos nucifera L.). Food Chemistry, 57, 299-304

Shenkin, A. (2006). The key role of micronutrients. Clinical Nutrition. 25, 113

United States Department of Agriculture (USDA). (2008) National Nutrient Database for Standard Reference, 2008.
Nuts, coconut water [Online]. Available: http://www.nal.usda.gov/fnic/foodcomp/cg i-bin/list_nut_edit.pl/, accessed on 9 December 2010. 